\title{
Monoclonal Antibody Me1-14 F(ab')2
}

National Cancer Institute

\section{Source}

National Cancer Institute. Monoclonal Antibody Me1-14 F(ab')2. NCl Thesaurus. Code C2409.

The F(ab)2 fragment of Me1-14, a murine IgG2a monoclonal antibody directed against proteoglycan chondroitin sulfate-associated protein expressed by gliomas and melanomas. By binding to proteoglycan chondroitin sulfate-associated protein, monoclonal antibody Me1-14 F(ab')2 conjug ated to a radioisotope may localize gliomas and melanomas when used as a tracer in radioimaging applications; in radioimmunotherapeutic applications, this agent conjug ated to a radioisotope may be used to deliver targeted radiotoxicity to these tumors. 